\title{
'A Spectacle for the Cameras': The survival of a Lakeland leisure tradition, 1930- c.1955
}

\author{
Rebecca Andrew
}

ORCiD: https://orcid.org/0000-0002-6803-7948

Department of History and Archaeology, University of Chester, Chester, UK

Binks Building, Parkgate Road Campus, Chester, CH1 4BJ. Email: r.andrew@ chester.ac.uk

\begin{abstract}
This article examines the survival of rushbearing, a rural leisure tradition in the English Lake District. As a region popular with tourists throughout the $20^{\text {th }}$ century, this case study offers important insights into how their presence shaped this 'traditional' leisure activity. Not only did annual rushbearing ceremonies offer opportunities for the region's sense of place to be presented to outsiders, they were also an important way for local communities to reaffirm their connection to the Lake District and its past. These occasions were, however, increasingly influenced by an awareness of external influences and outside judgements, as the region's popularity as a tourist destination boomed from the inter-war years. Although youth culture was increasingly standardised at a national level during this period, at a local level, young countrymen and women played an integral role in rushbearing's survival, which promoted an idealised version of 'traditional' country life. This annual community event is therefore a useful example through which to examine the interplay between rural leisure traditions, tourism, and the role of young people in the countryside during this period.
\end{abstract}

KEYWORDS: Lakeland, Authenticity, Cultural landscapes, Identity, Rural tourism,

Community

Word count: 11,070 


\section{Introduction}

Whilst there has been considerable academic interest in the Lake District as a 'national playground' across the twentieth century, little historical attention has focussed on the permanent residents of this region. ${ }^{1}$ This is particularly true in regard to the history of local leisure culture, which has tended to heavily foreground the experiences of outsiders and tourists to the region, at the expense of 'ordinary' inhabitants. ${ }^{2}$ In contrast, this article examines Lakeland and its leisure culture from the perspective of those who lived there. ${ }^{3}$ It does so in two specific ways; firstly, it takes the 'ancient' custom of rushbearing as a case study through which to explore the role of leisure traditions in village communities between the 1930s and 1950s. This was a period of considerable change and standardisation in national leisure habits and culture. It is argued here that whilst annual events such as rushbearing ceremonies were an important way for local communities in Lakeland to reaffirm their connection to the region and its past, they also offered opportunities for the region's

\footnotetext{
${ }^{1}$ Notable exceptions include Michael Huggins, “Sport helps make us what we are': The Shaping of Regional and Local Sporting Identities in Cumbria c.1800-1960', Transactions of the Cumberland \& Westmorland Antiquarian and Archaeological Society CW3, xii (2011),81-96; Lyn Murfin, Popular Leisure in the Lake Counties (Manchester: Manchester University Press, 1990); John K. Walton, \& John Duncan Marshall, The Lake Counties From 1830 to the midTwentieth Century: A Study in Regional Change (Manchester: Manchester University Press, 1981).
}

${ }^{2}$ See for instance: Douglas Hope, 'The Democratisation of Tourism in the English Lake District: The Role of the Co-operative Holidays Association and the Holiday Fellowship', Journal of Tourism History, 8, 2 (2016), 105-126; Robert Snape, 'The Co-operative Holidays Association and the Cultural Formation of Countryside Leisure Practice', Leisure Studies, 23, 2 (April 2004); John K. Walton \& Jason Wood, (eds) The Making of a Cultural Landscape: The English Lake District as Tourist Destination, 1750-2010, (London: Ashgate, 2013).

${ }^{3}$ Lakeland lies in the south-eastern corner of the Lake District, formerly in the county of Westmorland, now part of present-day Cumbria. Although sometimes used interchangeably with the 'Lake District', 'Lakeland' was the most commonly used term by inhabitants of this area during the period examined here, who referred to themselves as 'Lakelanders'. 
sense of place to be presented to outsiders. As one of the most popular and well-known Lakeland events during the period, rushbearing drew considerable crowds of residents and visitors each year. It repeatedly featured in guidebooks, the national press, and promotional literature on the Lake District throughout the period examined here. This material will also be used to examine how Lakeland was presented to external audiences. Importantly, however, evidence created within this area will be used in order to hear the voices of local residents, and the role this communal leisure activity played in their collective identities. Of particular interest here is evidence from the regional press, and oral history testimony with former rushbearers. ${ }^{4}$

In the context of this external interest in, and awareness of, rushbearing ceremonies, this article suggests that they were significant to the communities which maintained them year after year, as way of preserving distinctly localised aspects of leisure culture and links to the past. As this article will demonstrate, the region's increasing popularity with tourists, along with technological developments, provided fresh opportunities to share this image with a far wider audience. Connections between rural recreation and a sense of community identity, have been highlighted by a considerable number of sociological and anthropological studies. ${ }^{5}$ A common conclusion in these works, is that large annual leisure events are central

\footnotetext{
${ }^{4}$ The oral history testimony was collected by the Ambleside Oral History Group (AOHG). The AOHG archive holds more than 300 interviews with residents of Lakeland (both past and present), gathered from 1976 to the present day. The interviews are available at Ambleside Local Studies Library, as well as online at www.aohg.org.uk where the collection is searchable by keyword and categorised by subject.

${ }^{5}$ Maureen K. Porter, 'The Bauer County Fair: Community Celebration as Context for Youth Experiences of Learning and Belonging' Journal of Research in Rural Education, 11, 3 (Winter 1995), 143-146; Karen De Bres \& James Davis, 'Celebrating Group and Place Identity: A Case Study of A New Regional Festival', Tourism Geographies, 3 , 3 (2001), 326-337; Robyn
} 
to both a sense of cohesion and place identity within small rural communities, as well as reflecting the rise of cultural tourism. ${ }^{6}$ An historical case study of this nature therefore allows for a critical examination of the cultural relationship between rural communities and tourists, given that visitors were routinely present at rushbearing ceremonies throughout the period examined here.

Secondly, this article sheds light on the rushbearing experiences of local young people in this isolated rural region, from an historical perspective. Young people had a long history of association with ceremony, both within and beyond Lakeland. In the $18^{\text {th }}$ century, it was largely young women or 'rush maidens' who carried the bearings to the local church. Young countrymen and women are, however, noticeably absent from historical studies of rural traditions in the $20^{\text {th }}$ century. ${ }^{7}$ This omission is significant, given (as this article will

Eversole \& John Martin, ‘Attending 'Sheepvention': Culture, Identity and Rural Events', Rural Society, 15, 2 (2005), 148-164; Scott McCabe, 'The Making of Community Identity through the Historic Sporting Event: The Case of Ashbourne Royal Shrovetide Football', in David Picard \& Mike Robinson, (eds.) Festivals, Tourism and Social Change: Remaking Worlds, (Clevedon: Channel View, 2006), 99-118; Vasilios Ziakas \& Carla A. Costa, “Between Theatre and Sport' in a Rural Event: Evolving Unity and Community Development from the Inside-Out', Journal of Sport \& Tourism, 15, 1 (2010), 7-26.

${ }^{6}$ See for instance, Phil Hubbard \& Keith Lilley, 'Selling the Past: Heritage Tourism and Place Identity in Stratford-upon-Avon', Geography, 85, 3 (2000), 221-232; Roberta MacDonald \& Lee Jolliffe, 'Cultural Rural Tourism. Evidence from Canada', Annals of Tourism Research, 30, 2, (2003), 307-322; Meghan O'Brien Backhouse, 'Re-enacting the Wars of the Roses: History and Identity' in Hilda Keane \& Paul Ashton, People and Their Pasts: Public History Today (Basingstoke: Palgrave MacMillan, 2009), 113-130; John K. Walton \& Keith Hanley, Constructing Cultural Tourism: John Ruskin and the Tourist Gaze, (Bristol: Channel View Publications, 2010); Walton \& Marshall, Lake Counties.

${ }^{7}$ Although young people's presence in the countryside has featured in a range of academic studies, the focus is again, often on those playing the role of tourist. This is slowly changing, however, see for example Sian Edwards' recent work on young countrymen and women: Youth 
demonstrate) that the survival of such leisure traditions often rested on subsequent generations maintaining them. Careful analysis of the role that younger generations could play in their survival is therefore an important theme in this article. As such, it will be demonstrated that young countrymen and women in Lakeland were important to the persistence of rushbearing, at a time when the country's leisure culture was undergoing a period of homogenisation. As the inhabitants of a region with a long-established reputation as a tourist destination, young Lakelanders spent much of their time being watched by outsiders; both in their work (for example, in shops, cafes, or as domestic servants in hotels and guest houses) and in their leisure, at large annual public gatherings as well as on a more regular, informal basis during the summer season. Observation by external groups (usually tourists), can help to shape the way local residents think about themselves and their localities, as academic work from a range of disciplines has demonstrated. ${ }^{8}$

Within the scholarly work on tradition, rural communities have attracted attention from a range of disciplines, highlighting how the maintenance of cultural traditions can act as a tool that 'people use in the construction of their identity'. ${ }^{9}$ Eric Hobsbawm and Terence

movements, citizenship and the English countryside: Creating good citizens, 1930-1960, (Basingstoke: Palgrave Macmillan, 2017).

${ }^{8}$ Bob Bushaway, By Rite. Custom, Ceremony and Community in England, 1700-1880 (London: Junction Books Ltd., 1982); Tim Edensor, 'Performing Tourism, Staging Tourism: (Re)Producing Tourist Space and Practice', Tourist Studies, 1, 1 (2001), 59-81; McCabe, 'Making of Community Identity; Michael Huggins, 'The Regular Re-Invention of Sporting Tradition and Identity: Cumberland and Westmorland Wrestling c.1800-2001', The Sports Historian, 21, 1 (2001), 35-53.

9 Jocelyn S. Linnekin, 'Defining Tradition: Variations on the Hawaiian Identity', American Ethnologist, 10, 2 (May, 1983), 241. See also, Anthony P. Cohen (ed.), Belonging: Identity and Social Organisation in British Rural Cultures (Manchester, Manchester University Press, 1982), 65; Elizabeth Carnegie \& Scott McCabe, 'Re-enactment Events and Tourism: Meaning, 
Ranger were among the first historians to reveal how rituals and symbols presented as traditional and unchanging, were in reality subject to continual processes of change. ${ }^{10}$ This process is commonly referred to as the '(re)invention of tradition', as "“culture" and "tradition" are anything but stable realities handed down intact from generation to generation'. ${ }^{11}$ Indeed, many of the rituals and symbols presented as 'traditional' at rushbearing ceremonies were modified each year, in order to suit the current organiser's tastes, as well as the practical needs of the village. Despite these inconsistencies, they were presented as significant leisure traditions both within local communities and to tourists; something mirrored in more recent examples of 'traditional' rural leisure activities. ${ }^{12}$ Rushbearing therefore provides a significant case study through which to explore the historical role of tourism in shaping rural leisure culture and identity. It can also provide insights into issues of national importance during this period, such as perceived threats to a 'traditional' rural way of life, and the relationship between town and country.

The article begins with an explanation of Lakeland rushbearing and its history, before moving on to consider how rushbearing helped to maintain a localised sense of place for permanent residents of the region, which was presented to spectators and visitors. The discussion then turns to consider the role of local young people in its survival, during a period

Authenticity and Identity', Current Issues in Tourism, 11, 4 (2008), 349-368; O’Brien Backhouse, 'Re-enacting the Wars'; Shirley, Rural Modernity.

${ }^{10}$ Eric Hobsbawm \& Terence Ranger, (eds.) The Invention of Tradition (Cambridge: Cambridge University Press, 1983; 2003).

${ }^{11}$ Ibid; Allan Hanson, The Making of the Maori: Culture Invention and Its Logic', American Anthropologist, New Series, 91, 4 (December 1989), 890

${ }^{12}$ McCabe's research showed how such events are routinely presented to both locals and tourists as 'traditional', they are in fact subject to constant change and revision, McCabe, 'Making of Community Identity'. 
when traditional elements of rural life were perceived to be under constant threat from various outside influences, including standardised popular culture, and the impact of vast population movements during the Second World War. ${ }^{13}$ The final part of the analysis considers how the presence of tourists shaped both the ceremony itself, and the behaviour of participants. It pays particular attention to the role of modern technologies, such as photographic cameras and their impact on how the ceremony was presented to the annual crowds of spectators. It concludes with an assessment of what this case study can reveal regarding the relationship between tourism and leisure traditions in rural communities during this period.

\section{Rushbearing in Lakeland}

The ritual of rushbearing began as religious ceremony, which involved the annual 'carrying [of] rushes to the parish church on the anniversary of its dedication'. ${ }^{14}$ This served practical purpose, as sweet-smelling rushes were used to cover the earth floor of church and provide warmth for worshippers. Although it is generally thought that the ceremony was medieval in origin (although Roman roots have also been suggested), 'unbroken' records date back in Lakeland to the $17^{\text {th }}$ century. ${ }^{15}$ When church floors were flagged or tiled in the $19^{\text {th }}$

${ }^{13}$ Key surveys and commentaries on this issue include: Arthur Wilfred Ashby, 'The Effects of Urban Growth on the Countryside', The Sociological Review, 31, 4 (October 1939), 345-369; Cyril Joad, A Charter for Ramblers (London: Hutchinson, 1934); Ministry of Agriculture and Fisheries, The Practical Education of Women for Rural Life Report of the Sub-Committee of the Interdepartmental Committee of the Ministry of Agriculture and Board of Education (London: HMSO, 1928); Henry Morris, The Village College. Being a Memorandum on the Provision of Educations and Social Facilities for the Countryside, With Special Reference to Cambridgeshire (Cambridge: Cambridge University Press, 1924); Henry Vollam Morton, In Search of England (London: Methuen, 1927:1934).

${ }^{14}$ Bushaway, By Rite, 76-7.

15 'A Grasmere Rushbearing', The Times (Aug 10, 1921), 6. 
century, rushbearing died out in many areas across the country, surviving largely in northern England. Lakeland was one of the few places to continue this practice, which evolved into more of a formal procession involving the whole village. ${ }^{16}$ One of the earliest tourist accounts of the rushbearing at Grasmere was published in 1787 by James Clarke, in his Survey of the Lakes. ${ }^{17}$ In the early 1800 s, William Wordsworth participated in local rushbearing ceremonies, which he commemorated in The Excursion (1814) and 'Rural Ceremony', one of the Ecclesiastical Sonnets (1821-2). ${ }^{18}$ This cultural connection was increasingly highlighted to external audiences from the mid- $19^{\text {th }}$ century, as a raft of regional guides appeared to meet the demands and tastes of a mass tourism market, eager to explore the Lake District. Black's famous Guide to the Lakes, for instance, included several lines on rushbearing from The Excursion, which ended with Wordsworth's apparent desire for the ceremony to 'last for ever'. ${ }^{19}$ The need to preserve these 'precious rites and customs of our

\footnotetext{
${ }^{16}$ Rushbearing also continued in Lancashire after the practical need had ceased. There, rushbearing was incorporated into annual wakes festivals and rushes were displayed on a cart, rather than carried by individuals, as was the practice in Lakeland. The custom was taken over by young people and developed from a church-based festival to a focus for young men and violence, as described in Robert Poole, 'Samuel Bamford and Middleton Rushbearing' Manchester Region History Review, 8 (1994), 14-22.

${ }^{17}$ Hardwicke Drummond Rawnsley, Chapters at the English Lakes (Glasgow: James MacLehose \& Sons, 1913), 130; James Clarke, Survey of the Lakes of Cumberland, Westmorland, and Lancashire, Book VI (1787), 124.

${ }^{18}$ William Wordsworth, 'Rural Ceremony', No. XXXII of the Ecclesiastical Sonnets (1822); Wordsworth, W., The Excursion (1814). See also, Joshua Essaka, The Romantics and the May Day Tradition (Routledge, 2016).

${ }^{19}$ Wordsworth, The Excursion, ii, 577-80 quoted in Black's Guide to the Lakes 13th ed. (1865), 40. This quotation was included from at least the guide's second edition, published in 1844. As Yoshikawa points out however, the quote in Black's is taken out of context (it actually relates to a funeral procession). Saeko Yoshikawa, William Wordsworth and the Invention of Tourism, 1820-1900 (London: Routledge, 2016), 168.
} 
rural ancestry', was conveyed to readers of this guide, which also helped to shape the version of Lakeland life they expected to see upon arrival. ${ }^{20}$ This link was repeated in many subsequent tourist guides, reinforcing the 'ancient' nature of the ceremony and its significance to a national audience. ${ }^{21}$ Rushbearing accordingly became one of a list of attractions tourists sought out on their summer visit to Lakeland. ${ }^{22}$ His involvement certainly helped to make the ritual more widely known to those outside the region; an association which still endures today. ${ }^{23}$ By the inter-war years, the famous poet's earlier participation provided locals with a clear connection to the past and a source of cultural pride. ${ }^{24}$ Its survival was particularly important in the region by this point, as only four villages in Lakeland still maintained the tradition, including Ambleside and Grasmere. ${ }^{25}$ It is the rushbearing held annually in these two villages with which this article is concerned.

Both Ambleside's and Grasmere's rushbearing took place during the summer months. Ambleside's event took place on the last Saturday of July. Grasmere's followed shortly after, on the Saturday closest to $5^{\text {th }}$ August, St Oswald's Day, (to whom the village church was dedicated). These dates also coincided with the region's peak tourist season, and spectator

${ }^{20}$ Wordsworth, The Excursion, ii, 577-80 quoted in Black's Guide, 40.

21 See for instance, Ward, Lock \& Co., The English Lake District (London, 1884); Katharine Lee Bates, From Gretna Green to Land's End, (1907); Rawnsley, Chapters.

${ }^{22}$ Yoshikawa, William Wordsworth, 169. The level of interest was also reflected nationally, as reports of the village rushbearing appeared in The Times as well as a number of regional newspapers across the country, in both the 19th and 20th centuries.

${ }^{23}$ Yoshikawa, William Wordsworth, 168.

${ }^{24}$ Ibid.

${ }^{25}$ Rushbearing also took place in the villages of Warcop and Musgrave, which are outside of the geographical limits of this article. For a discussion of the ceremonies there, see Murfin, Popular Leisure, 56-59. 
numbers were therefore routinely boosted by holidaymakers. Both ceremonies included a procession of 'bearings', made from either bunches of rushes cut from the shores of a local lake, or more structed creations consisting of a frame in the shape of religious symbols (for example, a cross, the serpent on the pole, or the 'White Hand of St Oswald'), covered in local flora and fauna. ${ }^{26}$ The 'bearers' would process around the village, ending at the local church, where the bearings would be put on display and a short religious service was held. Regionally distinctive sports and a special tea followed (more will be said about this below) ${ }^{27}$ As part of the proceedings, every child and young person who participated was given a slab of 'rushbearing gingerbread', (which in Grasmere was stamped with 'St Oswald'), as a reward. ${ }^{28}$ This culinary element of the festivities (baked specifically for the event each year) provided another layer to the local distinctiveness of this event.

\footnotetext{
${ }^{26}$ Rawnsley, Chapters, 129.

${ }^{27}$ The sports were also regionally distinctive, including Cumberland and Westmorland-style wrestling, and fell running.
}

${ }^{28}$ There are conflicting accounts for when gingerbread first appeared as part of the ceremony; a late $19^{\text {th }}$ century text on Lakeland rushbearing claimed that the distribution of gingerbread by the Church replaced its monetary payment for rushbearers in 1830. Records for St Oswald's in Grasmere indicate that in 1857 , the Church also stopped funding gingerbread, 'and a voluntary gingerbread fund', collected from local residents, had since 'been in vogue', Martin Sampson, The Rushbearing (Leeds: Weekly Churchman Press, 1896), 19. However, a pamphlet produced in the 1980s, suggested that from 1819 there are records in the Churchwardens' accounts of payment for rushbearing gingerbread, The Rushbearing in Grasmere (Billingshurst: Weald Printers, Ltd., c. 1984). Either way, this suggests that its introduction can be traced to first decades of the 19th century. 
In common with many other leisure activities in Lakeland between the 1930s and the early 1950s, the annual rushbearing was largely organised from within local villages. ${ }^{29}$ Accordingly, there was a strong intergenerational theme to these events. Poole's examination of rushbearing in nineteenth century Lancashire, suggested that the ceremony was 'the physical representation of the pride, cohesion, prosperity, skill and sheer strength of the whole community. Male and female, young and old, participated' ${ }^{30}$ These were characteristics shared by rushbearing in a rural setting. The annual event attracted large numbers of Lakeland residents of all ages and classes, as well as those who had moved away from the region and returned in order to catch up with kith and kin. These events were, therefore, important in maintaining a sense of connection for both communities within the region, as well as those who had left the immediate area. They were also an element of the local leisure calendar in which whole communities could participate, at the same time and in the same place; vital for the maintenance of a shared identity in an isolated rural area. This communal activity extended into the days leading up to the event, where villagers would come together to collect natural materials for their bearings, and to compare their finished creations. The involvement of young people from both villages allowed them to be part of something that their parents were likely to have experienced and could still remember. ${ }^{31}$ Passing local leisure traditions down to younger generations was obviously important for their survival, but it also provided young and older members of the village with shared experiences and memories, based around a localised sense of place.

\footnotetext{
${ }^{29}$ Rebecca Andrew, The Leisure Identities of Rural Youth: Tradition, Change and Sense of Place in Lakeland, 1930s-early 1950s, Ph.D. thesis, Manchester Metropolitan University, (2013).

${ }^{30}$ Poole, 'Samuel Bamford', 15.

${ }^{31}$ Porter, 'Bauer County Fair', 143.
} 
In both villages, rushbearing tended to be organised primarily by a local authority figure, who co-ordinated other volunteers and participants. In Ambleside, Miss Routledge (Headmistress of Ambleside's infant church school until her retirement in 1935), was frequently referred to by oral history respondents as a key leadership figure. Grasmere's event was presided over during the period under review here, by Mrs Eleanor Rawnsley (widow of Canon Hardwick Rawnsley, co-founder of the National Trust), who lived in Allan Bank, (once occupied by Wordsworth and his family). ${ }^{32}$ The involvement of middle-class authority figures in the organisation of this community event, was representative of much of young people's leisure in Lakeland at this time, which was generally characterised by strong adult leaders. Both women were leaders of voluntary youth groups (such as the Girl Guides and Girls' Friendly Society) within their respective villages, and organised social gatherings including dances. The intergenerational nature of young workers' leisure in Lakeland marked their experiences out as distinctive from those of urban youth during this period. The lack of anonymity within local villages (a common characteristic of rural life) removed much of the agency exhibited by their urban counterparts during the same period, and left them with a deficit of distinct generational spaces. As a rule, their leisure experiences were marked by significant adult involvement and limited independence, which helped to sustain a sense of 'border maintenance' between local rural leisure habits and those in urban areas. It should not be assumed, however, that local young people in Lakeland were merely passive recipients in their leisure activities. ${ }^{33}$ Instead, they engaged in activities which, although often organised by adults, both rejected and mediated popular leisure trends into forms which fitted in with

\footnotetext{
${ }^{32}$ Miss Routledge died in 1950, and Mrs Rawnsley in 1959; the oral history testimony suggests both remained active in their local communities until the end of their lives.

${ }^{33}$ Leyshon, 'The Betweeness of Being', p. 18; R. Andrew, 'Social Dancing in 1930s Lakeland', Manchester Region History Review (2012).
} 
their identities as young countrymen and women. ${ }^{34}$ The discussion now turns to address how this localised sense of place was rehearsed and presented to both insiders and outsiders, through annual rushbearing ceremonies.

\section{Performing place, presenting the past}

Rushbearing was an important way for Lakeland communities to reaffirm their collective identity, whilst also presenting an idealised version of life in the countryside. The 1930s saw representations of the countryside heavily reliant on nostalgia, which in the case of Lakeland, can be described as the 'object of the romantic [tourist] gaze'. ${ }^{35}$ Increasing numbers of city dwellers went in search of the idealised images of country life they read about in the plethora of guide books and travel writing which emerged during this decade. ${ }^{36}$ As an 'ancient' ritual, with close connections to Wordsworth, Lakeland's annual rushbearing fitted this inter-war enthusiasm for a rural way of life thought to be rapidly disappearing. As a result of the growing interest in country life and culture, rural communities became increasingly aware that they were 'on display' to visitors who were 'economically important,

\footnotetext{
${ }^{34}$ For more on this, see Andrew, Leisure Identities.

${ }^{35}$ John Urry, The Tourist Gaze: Leisure and Travel in Contemporary Societies (London: Sage, 1990;
} 1996), 104. For work on the countryside and nostalgia, see: Catherine Brace, 'Looking Back: The Cotswolds and English National Identity c.1890-1950', Journal of Historical Geography, 25 (1999), 502-16; Paul Readman, 'The Cliffs are not Cliffs': The Cliffs of Dover and National Identities in Britain, c.1750-c.1950', History, 99, 335 (April, 2014), 241-269.

${ }^{36}$ A very small selection of the most influential works in this genre includes: Henry Batsford, How to See the Countryside (London: Batsford, 1940); Cyril E.M. Joad, The Untutored Townsman's Invasion of the Country (London: Faber and Faber, 1945; 1946); Harold John Massingham (ed.), The English Countryside: A Survey of Its' Chief Features (London: Batsford, 1939); H.V. Morton, In Search of England (London: Methuen, 1927); John B. Priestley, English Journey, (Penguin, 1934). 
but culturally rather threatening' ${ }^{37}$ As greater numbers of curious tourists arrived in Lakeland looking for signs of 'traditional' rural life, they brought with them elements of urban popular culture which jarred with this image (more will be said about this below). In this context, these rituals were not only a way of rehearsing local identity within local communities themselves; as a tourist destination, such events also allowed villages to present a specific and, as Urry suggested, an 'apparently authentic' sense of place to outsiders, highlighting their distinctiveness from the homogenised leisure trends of the decade. ${ }^{38}$ In the face of this cultural 'threat', the 'traditional' place identity of Lakeland was projected year after year to the large numbers of international tourists, who were increasingly present at both the Grasmere and Ambleside ceremonies, as reported in the local press:

Hundreds of holiday-makers swelled the ranks of the villagers, who left their homes en masse to line the route of the procession, and in the midst of such a typically English scene, it was strange to hear sentences in German, Dutch and French from interested foreign onlookers. The nasal tones of Americans from across the Atlantic were no less evident. ${ }^{39}$

It is important then, to consider the role tourism can play in not only how rural communities viewed themselves, but also the way they wish to be viewed by outsiders, through certain leisure practices. ${ }^{40}$ In the case of rushbearing, foregrounding the ceremony's links with the past were a central element of how local communities wanted to be viewed.

\footnotetext{
${ }^{37}$ Murfin, Popular Leisure, 56.

${ }^{38}$ Urry, Tourist Gaze, 104.

${ }^{39}$ Westmorland Gazette, 14 August 1937.

${ }^{40}$ Hanson, 'Making of the Maori'; Linnekin, 'Defining Tradition'.
} 
Continuities with the past were woven throughout the ceremonies in both villages. This included the procession itself, which followed a similar route walked by earlier village inhabitants for centuries and the bearings, carried in the procession, which depicted old religious symbols. Every bearer was responsible for creating their own bearing each year and decorating it with flowers, rushes and greenery. This provided the young people who took part with some creative freedom to design and decorate their own symbols for display, even though the symbols tended to remain the same each year. It was stipulated, however, that the bearings had to be made from local wild flowers and fauna and the adults who organised the event were known to get 'extremely annoyed', if anything other than local greenery was used for this purpose. ${ }^{41}$ The inclusion of wild flowers reinforced not only the specifically rural nature of this leisure activity but also a sense of place, which was suggested in the finer details, such as the use of highly localised elements, such as flowers. The celebration of local culture also extended to the music which accompanied the procession. In both Ambleside and Grasmere, the Rushbearing Hymn was sung by participants and spectators each year, accompanied by a local brass band. One participant recalled in later life, how ' $[\mathrm{w}] \mathrm{e}$ were taught to sing the rushbearing hymn as soon as we could learn to read and write' ${ }^{42}$ Other musical continuities were also evident, as the tune which Grasmere's procession marched to each year was composed by villager Jimmy Dawson 'the village fiddler for forty-six years,

\footnotetext{
${ }^{41}$ AOHG Respondent IN, born 1920.

${ }^{42}$ AOHG Respondent IZ1, born 1910. The Rushbearing Hymn was composed by Owen Lloyd, a local curate in the mid- $19^{\text {th }}$ century. A copy of the Hymn, and other music composed especially for the ceremonies in the two villages, can be found in Rawnsley, Rushbearing, 20-25. It is still sung at the Ambleside ceremony today, where printed copies are handed out for spectators to join in.
} 
who wrote his tune' in the early $19^{\text {th }}$ century. ${ }^{43}$ Such examples suggest that local people were taught from a young age what made their region distinctive and special and this was a sense which many carried with them into adulthood, expressed in later-life oral history interviews. There were however, contradictions within the cohesive identity the ceremony promoted. The 'Rushbearing Sheet' (which headed the procession), could only be carried by girls who attended the village school. Other young girls, who lived in the village but attended a school outside of Grasmere, were barred from this part of the event:

"I was never a Rush Girl... well you see, when you went to the Grammar school you went at eleven, well those on the Rush Sheet were always fourteen at Grasmere school. They never let anyone from the Grammar school be on the Rush Sheet... so I was never on it." 44

As this description suggests, although often seen as cohesive and inclusive spaces, villages could also exclude residents, as well as outsiders. ${ }^{45}$ It would appear, then, that maintaining this element of tradition in the presentation of collective identity, took precedence over the individual.

In addition to walking in the procession each year, Grasmere's and Ambleside's young people were involved in this event in number of other ways. As spectators, who watched the procession make its way around the village, as well as in support roles, serving refreshments as part of 'rushbearing tea' after the ceremony. This form of participation was

\footnotetext{
${ }^{43}$ Rawnsley, Chapters, 130-1.

${ }^{44}$ AOHG Respondent GN, born 1914.

${ }^{45}$ Michael Leyshon, 'The Betweeness of Being a Rural Youth: Inclusive and Exclusive Lifestyles', Social and Cultural Geography, 9, 1 (2008), 13-14.
} 
described by one woman as 'great fun really.... [it] was quite hard work but anything that you did like that was for the village and it was quite fun and it was social, you met people'. 46 For the women involved in this aspect of the event, the 'hard work' of belonging to the village community was justified through the social life and 'fun' it could offer. The rushbearing tea was served using 'special' crockery, which included 'enamel mugs with "Grasmere Rushbearing" on them'. ${ }^{47}$ These items not only commemorated the ceremony but also added a further sense of ownership to the event. By using these almost 'branded' items for the celebration tea, the village reinforced ties between itself and the ceremony. It is interesting to note that items such as these are often found in tourist resorts, where glasses, plates and cups can be purchased bearing the name of a town or resort. It is argued here that this element of the celebrations reflected a growing self-consciousness among local communities surrounding this tradition and its connection to a localised sense of place. By annually 'recreating' traditions in their leisure, young participants had already established a strong sense of place by the time they began working. Involvement as a spectator also meant that rehearsal of a local identity strongly associated with tradition was initiated from an early age and continued into the teen years. Young people's participation in a range of roles, were central to the survival of leisure traditions such as the rushbearing and therefore the distinctiveness of local identity. ${ }^{48}$

The importance of this particular event to these villages was immortalised in paintings by locally-based artists, upon which the ceremonies in Grasmere and Ambleside respectively, clearly left an impression. An art work by Frank Bramley R.A. in 1905, for example, was

\footnotetext{
${ }^{46}$ AOHG Respondent GN, born 1914.

${ }^{47}$ AOHG Respondent GN, born 1914.

${ }^{48}$ Andrew, Leisure Identities.
} 
purchased by village subscription and hung in Grasmere village hall in 1913, after being displayed at the Royal Academy. ${ }^{49}$ In 1944, Gordon Ransome, evacuated to Ambleside with the Royal College of Art, painted a 26ft mural of the village's rushbearing, on a wall in St Mary's Church, where the procession ended each year. ${ }^{50}$ In both cases, local people of all ages posed for the artists and were included in the finished piece. This not only endowed the paintings with an increased sense of authenticity but also created a personal link between the villagers and art works, which were displayed with pride in their respective villages. A number of young people were included in the Ransome painting and AOHG respondents expressed how they valued their involvement if they (or even a friend) had been included in the scenes. These paintings provided a further physical link of continuity between the ceremony and their lives. This inclusion could also create a sense of ownership between locals and the ceremony, as one respondent said of the Ambleside rushbearing, 'it belonged to the town'. 51

Figure 1. Postcard featuring Gordon Ransome's mural of Ambleside Rushbearing (1944) on the wall of St Mary's church, Ambleside. Scanned image from an original in author's personal collection.

\footnotetext{
${ }^{49}$ This painting still hangs in Grasmere Village Hall today, and can be viewed online at: http://www.nationaltrustcollections.org.uk/object/419408

${ }^{50}$ William R. Mitchell, Life in the Lake District: Pictorial Memories of a Bygone Age (Clapham: Dalesman, 1980), 26. Frank Bramley lived in Grasmere and was a member of the Royal Academy. Gordon Ransome was evacuated to Ambleside in 1940, along with the rest of the Royal College of Art for the duration of the war.

${ }^{51}$ AOHG Respondent HY, born 1919.
} 
The local press also helped to support both rushbearing's links with the past, as well as its highly localised connections. A description of the Grasmere rushbearing in 1937, claimed for instance, that if 'there had been no St. Oswald there would have been no Wordsworth'. ${ }^{52}$ Clearly, this was an overstatement, yet the emphasis placed on the connection between this Lakeland village and the famous poet, demonstrates the continued efforts which were made locally to maintain and promote links with the region's past and importantly, older leisure practices. Another way in which the ceremony allowed local communities to distance themselves from urban leisure habits, and particularly those of young city dwellers, was via its lack of commercialism. This added a further layer of authenticity to this event, removing it from the artificial attractions such as cinema chains, dance halls, and large sporting arenas, available in towns and cities during this period. It also placed them in contrast to the culture of urban tourists arriving in Lakeland in increasing numbers during the 1920s and 1930s, bringing with them gramophone music, advertising hoardings, petrol stations, and roadhouses. ${ }^{53}$ The only aspect of the ceremony which involved the exchange of money, was fundraising for the afternoon tea and the brass band's expenses. In the lead up to the rushbearing each year, young people often spent their spare time calling from house to house with collecting tins. In Grasmere, young women worked on a stall set up in aid of the ceremony, which sold items unavailable locally. ${ }^{54}$ It would appear then, that commercialism in the form of a stall was acceptable, if it supported a local tradition. This

\footnotetext{
52 Westmorland Gazette, 14 August 1937, 3.

${ }^{53}$ See for example Joad, A Charter for Ramblers, 171; Morton, In Search of England, 190-192, who both record the horrors of gramophone music, traffic jams, and other elements of modernity desecrating the Lakeland landscape.

${ }^{54}$ AOHG Respondent IN, born 1920. The items sold were 'trinkets' which included pencils, notebooks and toys, which, according to one respondent, the village children were not usually able to buy, as they 'didn't go into Ambleside to shop'.
} 
points to rural communities' ability to mediate unwelcome elements of popular leisure culture such as commercialism (the spread of which was vehemently criticised in rural spaces by contemporary writers), if it helped to secure its survival. ${ }^{55}$ The overall lack of commercial interest also conformed to the image of 'moral purity', commonly associated with the countryside, which again helped to mark the event out as distinctive and in opposition to urban leisure culture during this period. ${ }^{56}$

The essence of this festival was about celebrating 'simple' aspects of rural life which related back to an earlier time; as one interviewee suggested, the rushbearing was 'a ritual and they loved it. It was so simple and yet everybody loved it'. ${ }^{57}$ Descriptions by oral history interviewees of the 'simple' leisure activities enjoyed in their youth were often central to these narratives, as well as how these events were reported in the local press. Phrases frequently used to describe the ceremonies in the 1930s included 'charming', 'traditional', 'rustic' and 'simple'. This language was often employed by oral history respondents to frame their experiences of rushbearing, something which helped them with 'border maintenance' against an 'imagined [urban] other' which did not conform to these constructions of the 'rural idyll' 58 The erosion of these 'borders' between rural and urban leisure habits, became an

\footnotetext{
${ }^{55}$ See for instance, John B. Priestley, English Journey, (Penguin, 1934); Harold J. Massingham, Cotswold Country: A Survey of Limestone England from the Dorset Coast to Lincolnshire (London, 1941-2), originally published 1937; C.E.M. Joad, Book of Joad: A Belligerent Autobiography (London: Faber \& Faber, 1935), p. 192 \& 204, quoted in Catherine Brace, 'A Pleasure Ground for the Noisy Herds? Incompatible Encounters with the Cotswolds and England, 1900-1950', Rural History, 11 (2000).

${ }^{56}$ Essaka, Romantics, 46.

${ }^{57}$ Respondent HQ, born 1923.

${ }^{58}$ Leyshon, 'Betweeness of Being', 13-14.
} 
increasing cause of tension towards the end of the 1930s, as concerns were raised locally regarding the decline of young people's involvement in this event. This in turn was used as a tool for wider criticism of 'sophisticated modern' leisure, which threatened the stability of 'simple' rural life, by luring young countrymen and women away to urban centres. As such, the 'traditional' rushbearing ceremony became a vehicle through which to voice concerns regarding the increasing commercialisation of young people's leisure habits more generally. Despite the fact that in 1937 alone, 150 young people and children 'from the perambulator to the "long trousers" stage' took part in Grasmere's rushbearing, it was noted that local adults 'could be heard declaring that "the procession is not what it was -the young people imagine that they are too big for that sort of thing"". ${ }^{59}$ In the same year, an apparently contradictory report appeared and suggested that 'the simple rural appeal of an ancient custom had lost little of its attraction' to local young people 'in spite of the more sophisticated modern pleasures which few of them fail to experience'. ${ }^{60}$ Whilst ostensibly celebrating the continued involvement of young people in the 'ancient custom', this last remark can also be read as a reference to concerns prevalent in England throughout the 1930s, that modern commercialised leisure was eroding rural traditions. ${ }^{61}$ As the decade drew to a close, and Britain went to war, it became evident that these concerns were not totally unfounded, as local young people in their teens gradually became less involved in rushbearing. Outsiders continued to shape the ceremony, although in different ways to peacetime, due to their prolonged presence in the region.

\footnotetext{
${ }^{59}$ Westmorland Gazette, 14 August 1937.

${ }^{60}$ Ibid.

${ }^{61}$ See for example, The Daily Mirror, 16 February 1939, 18.
} 


\section{Spectators to participants: Rushbearing in wartime}

Before the Second World War, tourists at the annual rushbearing ceremonies were largely confined to the role of spectator. In wartime, however, there was shift in how outsiders were able to participate in these leisure traditions, as many evacuees were actively involved, and walked in the processions alongside local people. ${ }^{62}$ At the first rushbearing festival to take place in Ambleside after the outbreak of war for instance, 'children from Newcastle secondary and elementary schools, a girls' school from Liverpool, and boys' schools from Winchester and Filey', were 'invited to take part in the festival which has been observed for over a century'. ${ }^{63}$ In the following summer of 1941, the Westmorland Gazette reported that ' $[\mathrm{h}]$ undreds of visitors and evacuees joined in with the local residents in singing the ancient Rushbearing hymn'. ${ }^{64}$ Whilst significant alterations in the ceremony were recorded by the local press, they clearly continued to focus on the unchanging, 'ancient' nature of the event, as these extracts demonstrate. During a period of significant uncertainty, apparently consistent links to the past could provide local communities with a sense of stability. By incorporating children and young people from outside the region, distinctive elements of Lakeland's identity were maintained despite the mass influx of urban outsiders, who brought their own leisure habits and culture with them. That same year, there were over 300 bearings in the procession, a number of which were created 'by high school and

\footnotetext{
${ }^{62}$ The Westmorland Gazette estimated in autumn 1939 that approximately 10,000 evacuees from schools alone, had been received in the area since the beginning of September. In addition to the schoolchildren who arrived in Lakeland, 2200 private evacuees are recorded as arriving in Westmorland for the period June 1941-December 1942. Source: J.F. and Marjorie A. Brown Dow, A Survey of the Evacuation in Westmorland (Kendal: Westmorland County Council, 1946), 14-15.

${ }^{63}$ Westmorland Gazette, 20 July 1940, 4.

${ }^{64}$ Westmorland Gazette, 03 August 1941.
} 
elementary school children from the North-East Coast' ${ }^{65}$ This involvement of school pupils evacuated to the region in the early 1940s, marked a further change in the composition of the bearers, as younger children began to take centre stage, a feature which persisted from this point until the end of the period examined here. This boost in numbers from school children also accounted (at least in part) for the survival of the rushbearing festivals in both Grasmere and Ambleside, at a time when other community events in the region lapsed. ${ }^{66}$ Yet this act of inclusion can also be viewed as a conscious effort to control the flow of modern cultural influences, which young urban incomers represented. In the context of wartime 'border maintenance' between locals and outsiders shifted from a straightforward demonstration of local distinctiveness to visitors (whose role was that of passive observers), towards direct inclusion in the festival. ${ }^{67}$ Actively engaging outsiders in rushbearing educated them in a 'traditional' Lakeland leisure practice and helped to protect the future of such events, at a time when fresh concerns regarding the effect of urban incomers on local people and traditions were being voiced. ${ }^{68}$ Robert Poole noted that rushbearing in $19^{\text {th }}$ century Lancashire, continued 'to adapt to changing circumstances as [it] had always done'; a finding

${ }^{65}$ Westmorland Gazette, 03 August 1941.

${ }^{66}$ Grasmere's famous annual sports show, for example, was abandoned for the duration of the war. The survival of rushbearing in this period, however, could also be due to the considerable involvement of older women and children in the rushbearing; two groups who were not involved in war work or the national call up. The male-dominated Grasmere Sports would have struggled to maintain pre-war attendance and competitor figures in the face of such upheaval and population movement.

${ }^{67}$ Leyshon, 'Betweeness of Being', 13-14.

${ }^{68}$ In Lakeland, anxiety over the influence of outsiders on local traditions, was expressed through reports of local dialect being eroded by incomers. Several small reports on the infiltration of other dialects and accents in Lakeland, appeared in the Westmorland Gazette during the early years of the war: 'Dialect War', 30 September 1939, 5; 'A New Dialect', 13 April 1940, p. 4; 'Where Were We?', 19 October 1940, 5, and 'County of Many Tongues', 04 January 1941, 5. 
echoed in Lakeland during the war, where disruptions were negotiated through the inclusion of outsiders. ${ }^{69}$ This is something which undoubtedly helped the ceremony in both villages to survive into the post-war period. The involvement of outsiders (particularly evacuees) appears to have coincided with (and perhaps even prompted), the declining participation of local young people, however. After 1945, rushbearing's place as an occasion primarily for children was consolidated. $^{70}$

\section{Lakeland rushbearing after the war}

The young people who returned home to Lakeland after the war, had experienced different types of leisure through mixing with urban outsiders and it is likely that this also informed their view of simple, rustic activities such as rushbearing. Although the popularity of the ceremony persisted in the immediate post-war period, local young people continued to play a reduced role in the proceedings, possibly because their tastes were becoming more sophisticated and possibly as a result of their greater access to leisure outside of their villages after $1945 .{ }^{71}$ By the late 1940 s and early $1950 \mathrm{~s}$, it was harder to interest those in their teens and early twenties in events such as this, as oral testimony reveals:

When they were small they loved it but of course, as they grew older, they used to think - oh no, we don't want to. It began to be like that, which we hadn't really experienced. We never thought of it when we were teenagers, it was a thing we just always did. ${ }^{72}$

\footnotetext{
${ }^{69}$ Poole, 'Samuel Bamford', 1.

${ }^{70}$ This was a trend identified by Murfin as taking place in the 1930s, yet oral history testimony indicates that interviewees did not see children as the predominant focus of the ceremony before 1939.

${ }^{71}$ See Andrew, Leisure Identities.

${ }^{72}$ Respondent IN, born 1920.
} 
A heightened sense of connection to the region's past in response to the mechanical attractions of the town, were evident in reports of this ceremony throughout the immediate post-war years. Descriptions of the lifelong links between some local residents and rushbearing, for example, were characteristic of accounts which appeared in the Westmorland Gazette from the late 1940s onwards; something rarely alluded to in the newspaper during the 1930s. One such commentary recorded that there were 'not a few' local people 'who have been connected with the rushbearing for the greater part of their life'. ${ }^{73}$ The intergenerational nature of the ceremony, whereby 'generations of local families' and 'young and old' alike participated, continued to mark the event out as distinctive. However, reports in the local press now drew on these connections in relation to Lakeland's more well-known former residents:

Mention of the wishing gate [which one bearing took the form of that year] reminds one that Wordsworth and the rest of the family must have seen the festival frequently in those days. Of recent years I have seen a grandson watching and a great grandson and great great grandchildren taking part, also a grandson and great grandchildren of "Christopher North". 74

In this way, a further layer of 'authenticity' was added to the event, and as tourist numbers increased in region, this helped to reinforce a sense of continuity with the past in the

\footnotetext{
${ }^{73}$ Westmorland Gazette, 30 July 1949, 3.

${ }^{74}$ Westmorland Gazette, 06 August 1949, 3. Christopher North was the alias of John Wilson, a
} Scottish essayist, critic and poet, who was friends with Wordsworth and lived locally in the early decades of the eighteenth century. 
post-war period. ${ }^{75}$ Such statements also perhaps reflected a growing nostalgia over the loss of those in their teens and early twenties from the proceedings, as this change was more noticeable in the years immediately after the war. In addition to school children playing a more prominent role as bearers, it became common for mothers to walk in the procession whilst pushing their babies in prams decorated with flowers.

Figure 2. Young bearers (including those pushed in prams) line up for a colourful photo opportunity. Ambleside Rushbearing (1953). Image from author's personal collection.

The presence of outsiders also had an effect on the tone of these reports; as discussed earlier, there was an increasing self-consciousness in 1930s Lakeland, over the interest which rushbearing attracted from tourists and other external groups. These trends intensified in the post-war years, and the composition of audiences at these displays was often recorded in reports of the ceremonies. In 1950, spectators were described as a 'cosmopolitan crowd', which included 'Americans, Danes, Norwegians, French, Belgian and Indian visitors', who witnessed the 'time-honoured procession for the first-time' ${ }^{76}$ Descriptions such as these in the local press indicate that the spectators, who watched this 'rustic village pageant', were almost as important as the locals who participated in the ceremony and the local press was quick to note any drop in visitor numbers. ${ }^{77}$

${ }^{75}$ Urry, Tourist Gaze, 104. For more on the links between nostalgia and war, see Robert Hemmings, Modern Nostalgia: Siegfried Sassoon, Trauma and the Second World War (Edinburgh:

Edinburgh University Press, 2008).

${ }^{76}$ Westmorland Gazette, 12 August 1950, 3.

${ }^{77}$ Westmorland Gazette, 30 July 1949, 3. 


\section{Tradition, tourists and technology}

As we have seen, the presence of otherwise undesirable elements of urban popular culture were permitted, providing they were beneficial to the ceremonies. From the late 1930s, relatively new technologies such as motion picture cameras were gradually used to record these 'ancient' and 'traditional' events. The ability of local communities to mediate elements of modern leisure culture and technology, in order to promote or maintain rushbearing, will now be addressed in relation to the presence of tourists in the region.

From the 1930s, a number of technological developments in popular culture increasingly infiltrated older leisure habits in Lakeland, such as rushbearing. One woman, who spent in her teens in Ambleside during this period, recalled a growing trend for tourists who watched the processions to bring cameras with them; a development which began to alter the way in which the bearings were carried by young people in the procession:

...the band used to start up and they sang the Rushbearing hymn in Market Square, ... and then as all the cameras started appearing, they used to hold them up, the bearings up, you know, and all the bearings were held high as a spectacle for the cameras, you see. And that's grown stronger and stronger. ${ }^{78}$

In subsequent years, the Market Square in Ambleside became the main focal point for the use of modern technology to document this traditional rural celebration. The raising of bearings specifically for photo opportunities became something of a ritual in itself for Ambleside. As the desires of tourists increasingly infiltrated these 'ancient' processions

\footnotetext{
${ }^{78}$ AOHG Respondent HY, born 1919.
} 
during the period, those taking part in the rushbearing, became 'increasingly self-conscious tradition-bearers'. ${ }^{79}$ The growing numbers of visitors who watched the rushbearing also reflected the development of cultural tourism, the increasingly visual culture of the period and the growing importance of photography to tourists. ${ }^{80}$ Other modern influences were visible in Lakeland during the 1930s, when, for example, the rushbearing procession in Ambleside was filmed and shown in the region's cinemas 'which was a matter for great local pride, and doubtless a boost to the tourist trade' ${ }^{81}$ In 1943, the rushbearing was filmed for inclusion in a British Pathé newsreel, screened in cinemas across the country. In the clip, the young bearers were lined up for the camera to create a picturesque 'scene' and this too, undoubtedly increased the self-consciousness of locals regarding the 'gaze' of outsiders and the meaning of the festival. ${ }^{82}$ The film's narrator informs audiences that Ambleside's 'scenic beauty' includes a 'haven' of 'ancient stone bridges', which 'Wordsworth immortalised in his poem Evening Walk'. Moving onto the ceremony itself, we learn that rushbearing is a 'relic

${ }^{79}$ Poole, 'Samuel Bamford', 18.

${ }^{80}$ Jennifer Watts, 'Picture Taking in Paradise: Los Angeles and the Creation of Regional Identity, 1880-1920', in Vanessa R. Schwartz \& Jeannene M. Przyblyski (eds.), The Nineteenth Century Visual Culture Reader, Ch. 25; Douglas A. Brown, 'The Modern Romance of Mountaineering: Photography, Aesthetics and Embodiment', The International Journal of the History of Sport, 24, 1 (2007), 1-34.

${ }^{81}$ Murfin, Popular Leisure, 56. A film clip of the 1930 ceremony in Ambleside is available via the British Pathe digital archive, 'Quirky: Rush-Bearing Celebrations' (1930): https://www.britishpathe.com/video/VLVAC1T32HJBBL5ECB1T15959H2GX-QUIRKYRUSH-BEARING-CELEBRATIONS/query/rushbearing The wireless also documented elements of 'traditional' Lakeland life during this period. Wilfred Pickles, for example, broadcast with the BBC from Grasmere Village Hall in the 1930s, when the village brass band played for his show. The band was requested to play traditional songs and hunting tunes, which helped to reinforce a particular image of the region to listeners at home.

${ }^{82}$ British Pathe, 'Rushbearing Festival' (1943): https://www.britishpathe.com/video/rushbearingfestival/query/rushbearing 
of the early days', while the film clip shows 'young bearers' as they 'form up in procession and march' to the church. As the camera pans across a crowd of smiling children enjoying their annual sweet treat, the commentary informs us, 'their good deed done for another year, the children are rewarded with lumps of gingerbread' ${ }^{83}$ Coverage of the rushbearing is framed using language and imagery conforming to the idealised view of 'simple' rural life at this time (something particularly important during the upheaval of wartime). It also points to the importance of participation in these leisure traditions from an early age, as the children's 'good deed' (ensuring the survival of the festival for another year) is recognised and 'rewarded' with locally distinctive confectionary. The presence of film cameras at the ceremony (especially the close-up shots), would undoubtedly have made participants aware that their activities were being recorded for an external audience. It would appear then, that as the twentieth century progressed, this traditionally inward-looking ceremony became more conscious of external influences and judgements on a number of levels, as an increasingly public image of Lakeland was constructed in the process. Ransome's church wall painting of the Ambleside rushbearing, for instance, was subsequently photographed and published as a postcard, providing visitors with a distinctive snapshot of the region to take away with them, or send home to friends and family (see Figure 1).

Figure 3. The procession just below Ambleside's market cross. Ambleside Rushbearing (1953). Image from Author's own collection.

Developments in modern technology, such as cameras, were welcome at the festival when they enhanced local traditions. ${ }^{84}$ When the 'neon attractions' of the town competed for

\footnotetext{
${ }^{83}$ Ibid.

${ }^{84}$ Elizabeth Edwards has examined this dynamic in: The camera as historian: Amateur photographers and historical imagination, 1885-1918, (Durham, N.C.: Duke University Press, 2012).
} 
the leisure time of young people, however, they were criticised and used to reinforce the differences between 'simple rural' attractions and 'more sophisticated [urban] pleasures'. ${ }^{85}$ Such examples also indicate a growing concern within local communities in Lakeland regarding the potential of homogenised leisure to draw young people away from village spaces. Perhaps in response to this change, the ceremony was used as a vehicle to criticise modern leisure habits, whilst celebrating the survival of this tradition in the face of homogenised and 'mechanised' pastimes, as this excerpt from the Westmorland Gazette in 1949 demonstrated:

Who says the mechanical-mindedness of the present day has stifled all romance and love of ancient history? Saturday night's commemoration was a definite refutation of such a contention. It shows in Lakeland there still exists a very solid affection for the love and tradition of the countryside and an appreciation of the beautiful flowers, and rushes green, which adorn the summer landscape. ${ }^{86}$

This 'mechanical-mindedness' is as much a reference to technological developments in leisure, such as the cinema and wireless, as it is to the labour-saving devices of the day, and points to a persistent tension between 'sophisticated', urban leisure and the 'simple' rural habits embodied in Lakeland's annual leisure traditions, such as rushbearing.

Rushbearing in both villages survived the spread of homogenised leisure habits in the first half of the twentieth century, although the use of photographic equipment was a growing

\footnotetext{
${ }^{85}$ Frederick George Thomas, The Changing Village, (London: Thomas Nelson, 1939), 54.

${ }^{86}$ Westmorland Gazette, 30 July 1949, 3.
} 
occurrence at ceremonies from the 1930s. By the early 1950s, the use of the Market Square in Ambleside as a ritual photo opportunity had become an integral part of the display, which prompted a 'whole battery of cameras' to 'set a-clicking'. ${ }^{87}$ As the Westmorland Gazette reported, '[w]ith the words of command "Raise your bearings", about 350 Ambleside children lifted their emblems, made of wood and decorated with all types of flowers, and turned Ambleside's Market Square into a blaze of colour on Saturday afternoon' ${ }^{88}$ This development also influenced the Grasmere procession, where the 'children, with their bearings, stood on the churchyard wall from 4-30 p.m. until 5 p.m. while parents and visitors were busy taking photographs' ${ }^{89}$ Notably in Grasmere, it was only the children who were included in these 'snapshots' of the event, something which other studies have highlighted as a common occurrence in the ways tourists choose to construct visual souvenirs of places they visit. ${ }^{90}$ Bearers were no longer only on display for the duration of the procession; they were now instrumental in providing an idea of Lakeland life for tourists to take away with them. One of these photos was included on the front page of the Westmorland Gazette; the first time the rushbearing was featured so prominently in the period examined here. The presence of photography was not an entirely new phenomenon, however, as it was noted in 1913, that '[a]t half-past four the customary crowds and the customary photographers had gathered in the Church-road to inspect the 'bearings' which had been arranged for view upon the

\footnotetext{
${ }^{87}$ Ibid

${ }^{88}$ Westmorland Gazette, 04 August 1951, 3.

${ }^{89}$ Westmorland Gazette, 15 August 1953, 3.

${ }^{90}$ Palloma Menezes 'Tourists' Photographic Gaze: The Case of Rio de Janeiro Favelas', in Richard Sharpley \& Philip R. Stone (eds.) Tourist Experience: Contemporary Perspectives, (Abingdon: Routledge, 2011), p. 99; Mike Robinson \& David Picard (eds), The Framed World: Tourism, Tourists and Photography, (Farnham: Ashgate, 2009).
} 
churchyard wall' ${ }^{91}$ The focus at this time however, appears to have been on the colourful, visual display the bearings provided photographers, rather than the bearers themselves, who in later years were also lined up on the wall for inspection and snapshots by increasing numbers of people, as ownership of this mobile technology became more common.

Importantly, these photographs all helped to spread the image of Lakeland as a traditional and unchanging rural idyll, using elements of modern culture and technology, which were accepted as long as they helped to promote or commemorate this localised festival. Where they threatened or challenged the existence of older leisure forms however, especially in regard to young people, they were criticised and resisted. By the early 1950s it is clear that very young children played a significant part in the ceremony and this continued therefore to impart a particular sense of place in local people from an early age, as well as the tourists who observed them. The focus on children when tourists and locals created visual records of the ceremonies, reinforced the idea that Lakeland communities and their leisure practices were routinely on display to outsiders, and were of interest to external audiences.

\section{Conclusion}

Rushbearing offers a significant case study through which to explore the historical role of tourism in shaping rural leisure culture and identity in the first half of the twentieth century. Walton and Marshall surmised that in the years preceding 1939 'there was an increasing tendency [in Lakeland] to display regional cultural self-awareness through... local traditions and ceremonies which were peculiar to an area'. ${ }^{92}$ Participants in these communal celebrations were often very sensitive to the presence of outsiders, whose attendance gave

\footnotetext{
${ }^{91}$ Rawnsley, Chapters, 131-2.

${ }^{92}$ Walton \& Marshall, Lake Counties, 16.
} 
Lakeland communities opportunities to 'project' a particular image or sense of place to them, as well as to audiences further afield. These occasions had long been important to village communities in Lakeland for both celebrating aspects of their past and appealing to tourists who visited the area. This self-awareness was clearly visible in the community event examined in this article. Annual gatherings such as rushbearing were important aspects of the region's leisure calendar and helped to maintain community ties. By celebrating the past in their leisure choices, local communities could suspend the influence of mass public culture and concentrate on what made them distinctive. ${ }^{93}$ Although Murfin argued that events such as rushbearing became more child-focussed during the 1930s, there is evidence to suggest that this local tradition remained important to those in their teens, as well as older generations throughout the inter-war years, when young people continued to play a central role in the ceremonies. Local young people played a significant and particular part in them, at a time when their involvement was viewed as vital to the survival of 'authentic' rural traditions in an age increasingly preoccupied with 'modern' pastimes. The commemoration of these events in art, poetry and song added to a sense of ownership in local communities and the 'specialness' of these events remained with the interviewees into old age. In wartime, the involvement of external groups (somewhat ironically), ensured the survival of this localised tradition into the post-war period. These events were strengthened through both their active participation as bearers, as well as spectators, which facilitated 'image building' and encouraged 'the creation of regional identity' for outside audiences, as well as locals. ${ }^{94}$ After the war, changes to Lakeland rushbearing in both villages was at least partially attributable to the presence of tourists in the region, who demanded that 'the culture as well as the scenery of the lakes be

\footnotetext{
${ }^{93}$ Porter, 'Bauer County Fair', 141.

${ }^{94}$ Reinhard Bachleitner \& Andreas H. Zins, 'Cultural Tourism in Rural Communities: The Residents' Perspective', Journal of Business Research, 44, 3 (March 1999), 207.
} 
made available, suitably embellished where necessary, for the entertainment of visitors' ${ }^{95}$ From the early 1930s, rushbearing was capable of attracting considerable audiences from outside the region, as well as the attention of wider groups, through newsreels and the national press. This was encouraged by the growing use of technological equipment to document the region on film. Culturally threatening elements of urban popular culture (such as the cinema) were, therefore deemed acceptable through their promotion of local traditions and a sense of place to wider audiences. ${ }^{96}$ The ability of such traditions to mediate the involvement of external influences such as tourist cameras, or evacuees in wartime however, was crucial to their survival.

\section{Epilogue: Rushbearing in the $21^{\text {st }}$ century}

Rushbearing continues to be a fixture in the Ambleside and Grasmere leisure calendars to this day. Visitors to the region still take part in the ceremony as spectators and in the procession itself. The commemoration of rushbearing via new technologies remains a feature of the event in both villages, as visitors and locals photograph and film the bearers (now on smartphones), often before uploading images of this Lakeland '\#tradition' to social media channels such as Twitter, Facebook, and YouTube. Grasmere Rushbearing has its own Twitter account, which captures preparations for the ceremony, whilst advertising it as a tourist attraction to a wider audience. Organisers in Ambleside, increasingly use Facebook to recruit local volunteers to help plan, promote and participate in the ceremony. Digital discussions of Ambleside's rushbearing, frequently include posts about its future and any perceived lack of interest from local residents, echoing concerns of earlier generations in the

\footnotetext{
${ }^{95}$ Murfin, Popular Leisure, 106.

${ }^{96}$ Ibid.
} 
village.$^{97}$ In late 2019 , one organiser suggested that perhaps the two villages could work together more closely to support their respective celebrations, 'we are all of the same stock and with modern communications I'm sure the distance between the villages wouldn't be an obstacle, each keep its own identity but liaise between the two [organising] committees' ${ }^{98}$ It appears that the digital age is beginning to shape the ceremony in new ways, which may help to ensure its survival long term.

Broader interest in these annual celebrations also persists. In July 2018 for example, Ambleside's rushbearing featured in Lake District Life \& Lancashire Life magazine. ${ }^{99}$ The article focused on interviews with a current 'ad hoc' community organiser, and a resident, whose involvement stretched back to 1924. Perhaps unsurprisingly, the piece covered the standard 'historic tradition' narrative of the ceremony, which 'epitomises the cultural landscape that was key in the Lake District being awarded World Heritage status' ${ }^{100}$ Interestingly however, it also discusses a recent external threat, in the form of 'backpackers and others clutching bouquets from local shops, some still in branded plastic bags', who joined the procession'. ${ }^{101}$ The inclusion of this tourist 'rabble', it is claimed, affected the local perception of the ceremony to such an extent, that community support 'was nearly lost when the traditional flavour was seen to be undermined'. ${ }^{102}$ Symbols of modern-day consumer culture were clearly marked out for special criticism here; the flowers carried by the outsiders

\footnotetext{
${ }^{97}$ See for example, 'Volunteers needed to keep Grasmere Rushbearing going', Westmorland Gazette, 6 April 2019; see also the discussions on the Ambleside Rushbearing Facebook page:

https://www.facebook.com/Ambleside-Rushbearing-1461511630756758/

${ }^{98}$ Post on Ambleside Rushbearing's Facebook page, 1 December 2019.

99 ‘Bearing with tradition', Lake District Life \& Lancashire Life, July 2018, 94-97.

${ }^{100}$ Ibid, 95

${ }^{101}$ Ibid, 95

${ }^{102}$ Ibid 95
} 
were shop-bought (not collected from the local natural environment) and displayed to spectators in 'branded' as well as 'plastic' bags. ${ }^{103}$ This not only resonates with the disapproval of earlier generations of villagers regarding visitors who symbolised an urban, commercial 'other', but also current fears within society regarding tourism-based environmental damage. ${ }^{104}$ Distancing these 'traditional' activities from urban culture is also apparent in the ongoing stipulation that bearings are composed 'mainly of rushes cut from nearby lake shores' and 'are highly decorated with mosses, flowers and greenery' largely taken from the local area. ${ }^{105}$

Notwithstanding this element of continuity, in 2018 a rush cart was added to the procession, after a relative of the long-standing participant interviewed for the Lancashire Life article, 'saw something similar' in Saddleworth, Greater Manchester. ${ }^{106}$ This is reminiscent of the ability of earlier generations within Lakeland communities to mediate elements of modern leisure culture and technology, in order to promote or maintain their leisure-time traditions. In this instance, a feature from rushbearing in an urban, industrial setting was deemed acceptable, as it provided an extra 'spectacle' for observers and an additional opportunity for local residents to participate. In line with earlier manifestations of this Lakeland tradition then, both ceremonies continue to adapt and change, according to local needs and trends.

\footnotetext{
${ }^{103}$ Ibid 95

${ }^{104}$ National Parks UK, 'The positive and negative impacts of tourism': https://nationalparks.uk/students/ourchallenges/tourism/impactsoftourism

${ }^{105}$ Ambleside Online, 'Rushbearing': https://www.amblesideonline.co.uk/useful-information/localevents/rushbearing/

106 'Bearing with tradition', 96
} 
Author disclosure statement

No potential conflict of interest was reported by the author.

Notes on contributor

Rebecca Andrew is Lecturer in Historic Landscapes and Environments in the Department of History and Archaeology at the University of Chester. Her research and teaching interests are particularly focused on how landscape can shape the construction of identity, sense of place, and belonging. Rebecca obtained a Ph.D. in History from Manchester Metropolitan University in 2013 (on which the research for this article is largely based), after also completing her undergraduate studies there. She has presented papers on her research at conferences organised by the Leisure Studies Association, Royal Historical Society, and the Agricultural History Society. 